\title{
KEGIATAN PENDAMPINGAN PENYUSUNAN DOKUMEN INSTRUMEN AKREDITASI SATUAN PENDIDIKAN 2020 DI SD NEGERI LATE
}

\author{
Melkior Wewe ${ }^{1)}$, Maria Desidaria Noge ${ }^{2)}$, Ermelinda Yosefa Awe ${ }^{3)}$, Yosefina Uge Lawe ${ }^{4)}$, \\ 1)Program Studi Pendidikan Matematika, ${ }^{2,3,4)}$ Program Studi PGSD \\ 1,2,3,4)STKIP Citra Bakti \\ 1) melkiorwewe1@gmail.com, ${ }^{2)}$ ennynoge@gmail.com, ${ }^{3)}$ ermelindayosefaawe8@gmail.com, \\ 4) yosefinagelawe@gmail.com
}

\begin{tabular}{ll}
\hline Historiartikel & Abstrak \\
\cline { 2 - 3 } Received: & Akreditasi sekolah dan madrasah merupakan proses penilaian \\
Accepted: & yang dilakukan secara komprehensif terhadap kelayakan \\
30 April 2021 & Sekolah/Madrasah, yang hasilnya diwujudkan dalam bentuk \\
Published: & akuntabilitas publik yang dilakukan oleh suatu lembaga yang \\
mandiri dan profesional, yang disebut dengan BAN S/M. & Pelaksanaan akreditasi dapat ditinjau dari dua hal yang dinilai, \\
& yaitu review pemenuhan administrasi (compliance) dan Kedua \\
& terkait kinerja satuan pendidikan (performance) untuk efisiensi \\
dan pelaksanaan yang simple dan akuntabel. Hasil wawancara \\
dengan kepala Sekolah bahwa SDN Late sudah melaksanakan \\
delapan Standar Nasional Pendidikan namun regulasi yang \\
mengatur tentang perubahaan sistem akreditasi oleh Badan \\
Akreditasi Nasional tentang perubahan sistem akreditasi, \\
(compliance) menjadi berbasis kinerja (performance), yang \\
ditekankan pada 4 Komponen utama yang dinilai adalah mutu \\
lulusan, proses pembelajaran, mutu guru, serta manajemen \\
sekolah/madrasah belum sepenuhnya di pahami oleh Kepala \\
sekolah maupun tenaga pendidikan dan tenaga kependidikan di \\
SDN Late. Luaran kegiatan pengabdian berupa; 1 ) pemahaman \\
akan pentingnya akreditasi sekolah, memahami alur penyusunan \\
borang akreditasi dan dokumennya. Dengan adanya kegiatan \\
pengabdian masyarakat ini berdampak pemahaman tentang \\
pentingya akreditasi sehingga akan tumbuh kesadaran dan \\
tanggung jawab sekolah dalam menjamin mutu pendidikan yang \\
berkualitas.
\end{tabular}

Kata-kata Kunci: pendampingan akreditasi, IASP 2020 
Abstract. School and madrasah accreditation is a production process carried out comprehensively towards the feasibility of schools / madrasahs, the results of which are manifested in the form of public accountability carried out by an independent and professional institution, called BAN S / M. The implementation of accreditation can be viewed from two things: wrong, namely a review of administrative compliance (compliance) and secondly related to the performance of the education unit (performance) for efficiency and simple and accountable implementation. The results of the interview with the school principal stated that SDN Late has implemented eight National Education Standards but the regulations governing changes to the accreditation system by the National Accreditation Board regarding changes to the accreditation system, (compliance) to be performance based, which emphasizes 4 main components which are: The quality of graduates, the learning process, the quality of teachers, and the management of schools / madrasahs are not yet fully understood by the principal, as well as education personnel and education personnel at SDN Slow. The output of service activities is in the form of 1) understanding the importance of school accreditation, understanding the flow of accreditation preparation and documents. With this community service activity, it has an impact on understanding the importance of accreditation so that school awareness and responsibility will grow in ensuring the quality of quality education.

Keywords: Accreditation, IASP 2020

\section{PENDAHULUAN}

Soedjadi (Wewe, 2014) abad 21 akan diwarnai persaingan dalam bidang bidang kehidupan, oleh karena itu Indonesia mutlak perlu memiliki warga negara yang bermutu dan berkualitas tinggi. Warga negara yang bermutu dan berkualitas tinggi di hasilkan oleh lembaga pendidikan yang bermutu. Karenanya diperlukan sumber daya manusia yang bermutu tinggi yang mampu menguasai dan mengembangkan ilmu pengetahuan dan tekhnologi, serta dapat memanfaatkannya untuk kesejahteraan bangsa. Kelayakan Lembaga pendidikan sekolah/madrasah dapat diwujudkan dalam bentuk akuntabilitas publik melalui proses akreditasi sekolah/madrasah yang beguna untuk menilai lebaga pendidikan tersebut secara komprehensif (Antonius, 2017). Bergesernya mekanisme akreditasi pada jenjang pendidikan dasar sampai jenjang pendidikan tinggi maka perlu maka dituntut suatu pemikiran yang cepat respon terhadap perubahaaan-perubahaan yang terjadi. Tilaar (dalam Wewe, dan Kau, 2019), pola pikir yang konvensional dalam menghadapi suatu tantangan menyebabkan timbulnya kegagalan, namun jika tantangan tersebut dihadapi dengan pola pikir yang baru produk atau luaran yang dihasilkan memiliki kualitas yang bemutu dan mampu bersaing di dunia kerja. UUD 1945 Pasal 31, tentang pendidikan menyatakan dengan jelas bahwa Pemerintah harus memajukan pendidikan dengan terselenggaranya sistem pendidikan nasional yang bermutu, dan berahklak mulia, yang selanjutnya diatur dalam Undang-Undang No 20 tahun 2003 tentang sistem Pendidkan nasional. Kebijakan Nasional dan standar nasional dalam menjamin mutu pendidikan sehingga tercapainya pemenuhan Standar Nasional Pendidikan (SNP) dituangkan dalam Undang-Undang Nomor 20 Tahun 2003 pasal 50 ayat 2, dan pasal 60 ayat 1 yang dijadikan sebagai acuan proses untuk mengetahui kelayakan mutu suatu satuan pendidikan dari jenjang pendidikan dasar sampai jenjang pendidikan tinggi baik itu jalur pendiidkan formal maupun non formal yang dilakukan oleh pemerintah, atau lembaga khusus yang independen sebagai bentuk 
pertanggung jawaban mutu secara komprehensif, obyektif dan transparan sesuai dengan instrumen atau indikator yang telah ditetapkan oleh Badan Akreditasi Nasional M. Zulkifli, (2015) Minuchin, (2003), sehingga satuan pendidikan atau sekolah memperoleh gambaran sebenarnya tentang mutu dari sekolah tersebut (Subijanto \& Siswo Wiratno, 2012).

Lembaga pendidikan dituntut untuk menghasilkan luaran berkualitas yang mengacu pada standar mutu sebagai landasan yang sudah disepakati, sehingga dapat diukur dan ditentukan (Malik, Abdul, dkk. 2021). Pasal 60 dalam Undang-undang Sistem pendidikan Nasional menyebutkan Pemerintah mengupayakan untuk meningkatkan kualitas dan kelayakan mutu program pendidikan secara berkelanjutan dan terukur pada jalur pendidikan formal dan non formal pada jenjang dan jenis pendidikan dilakukan dengan akreditasi.

Kelayakan Lembaga pendidikan sekolah/madrasah dapat diwujudkan dalam bentuk akuntabilitas publik melalui proses akreditasi sekolah/madrasah yang beguna untuk menilai lebaga pendidikan tersebut secara komprehensif (Antonius, 2017). Proses akreditasi untuk penilaian sebuah lembaga pendidikan dilakukan oleh suatu lembaga yang mandiri dan profesional, yang disebut dengan BAN-S/M (Malik, Abdul, dkk. 2021).

Tahun 2019 BAN-S/M telah menetapkan perangkat akreditasi yang baru, atau disebut dengan Instrumen Akreditasi Satuan Pendidikan (IASP-2020) yang diigunakan pada tahun 2020. Dinamika dalam dunia pendidikan yang banyak mengalami perubahaan merupakan suatu alasan perubahaan instrumen akreditasi. Instrumen akreditasi yang digunakan pada tahun 2020 menggunkan sistem penilaian berbasis administrasi (compliance) menuju penilaian berbasis kinerja (performance based) atau dari rules to principles. Perubahaan instrumen akreditasi merupakan suatu bagian penting dari upaya BAN S/M sebagai lembaga independen dalam penjaminan mutu pendidikan untuk terlibat dalam mendorong continous improvement.

Penelitian yang dilakukan oleh Setiawan et al (2018) tentang korelasi delapan standar nasional Pendidikan dan ujian Nasional berbasis kompetensi berkisar pada angka $21 \%$. Hasil analisis model struktural menyimpulkan bahwa indikator dalam instrumen akreditasi terdahulu tidak sesuai dengan dinamika pendidikan saat ini dan perlu melakukan evaluasi terkait instrumen akreditasi. Rendahnya hasil penilaian komponen SNP sangat dipengaruhi oleh faktor manajerial kepala sekolah, guru dan tenaga pendidik lainnya (Wahyuni, 2018). Faktor lainnya adalah kurangnya persiapan sekolah khususnya dalam penyiapan dokumen fisik, terbatasnya waktu dalam melakukan evaluasi diri serta koordinasi yang tidak maksimal antara tim borang sekolah (Sholihin et al., 2018).

Pelaksanaan akreditasi ditinjau dari dua hal yang dinilai. Pertama adalah hal-hal yang berkaitan dengan review pemenuhan administrasi (compliance) melalui pencarian data dalam Dapodik dan/atau sumber lain. Kedua adalah hal-hal yang terkait kinerja satuan 
pendidikan (performance) melalui pengamatan langsung ke sekolah/madrasah. Sebagai bagian dari pendidikan bermutu, pelaksanaan akreditasi dari dua hal tersebut yaitu compliance dan performance, sekolah yang tidak memenuhi aspek compliance maka tidak dapat dilanjutkan dengan penilaian performance. Hal ini dilakukan untuk efisiensi dan pelaksanaan yang simple dan akuntabel. Penilaian Compliance yang akan dinilai melalui compliance berkaitan dengan mutu lulusan, proses pembelajaran, guru, manajemen sekolah/madrasah, kurikulum, penilaian, sarana dan prasarana, dan pembiayaan. Penilaian Performance Hal-hal yang akan dinilai untuk aspek performance adalah terkait dengan mutu lulusan, proses pembelajaran, guru, dan manajemen sekolah/madrasah melalui kunjungan ke sekolah/madrasah. Penilaian menurut Mardapi (2008) Popham, (2009) yang dikutip oleh (Wewe, Rawa, Bela, Wangge, \& Bhoke, 2020), memiliki manfaat untukmenetukan suatu keberhasilan suatu mutu pendidikan, sehingga dapat memberikan dampak yang yang signifikan dan dijadikan sebagai untuk dasar dalam merumuskan suatu kebijakan atau program kerja yang baru. .

Tahun 2021 di propinsi NTT sekolah yang akan dilakukan akreditasi sebanyak 633 sekolah dan Sekolah Dasar Negeri (SDN) Late adalah salah satu dari 633 yang diprioritaskan. Sekolah Sekolah Dasar Negeri (SDN) Late merupakan salah satu sekolah dasar yang ada di Kabupaten Ngada, tepatnya di kecamatan Golewa Barat yang menjadi prioritas BAN S/M Propinsi NTT untuk dilakukan akreditasi pada tahun 2021 karena SDN Late pada tahun 2021 akan menamatkan siswa namun sekolah tersebut belum diakreditasi.

Hasil wawancara dengan bapak Neta, Johanes Brechmans, S.Pd selaku kepala Sekolah bahwa SDN Late sudah melaksanakan delapan Standar Nasional Pendidikan namun regulasi yang mengatur tentang perubahaan sistem akreditasi oleh Badan Akreditasi tentang perubahan sistem akreditasi, dari perubahan paradigma berbasis kepatuhan administratif (compliance) menjadi berbasis kinerja (performance), yang ditekankan pada 4 Komponen utama yang dinilai adalah mutu lulusan, proses pembelajaran, mutu guru, serta manajemen sekolah/madrasah belum sepenuhnya di pahami oleh Kepala sekolah maupun tenaga pendidikan dan tenaga kependidikan di SDN Late. Hasil wawancara dengan beberapa guru, bahwa guru-guru mengalami kesulitan untuk menyusun dokumen dan mempersiapkan bukti fisiknya. Instrumen akreditasi satuan pendidikan (IASP) 2020 sangat jauh berbeda dengan instrumen pada tahun-tahun sebelumnya, namun Rahman, et al (2017) menjelaskan bahwa permasalahan utama dalam pemahaman akreditasi bukan pada instrumennya, namun bagaimana sekolah melakukan evaluasi setiap waktu dengan mengacu pada delapan Standar Nasional pendidikan, sehingga sekolah mampu melihat kelemahan-kelemahan dan dapat menemukan startegi yang tepat dalam menyusun prograa kerja yang baru dan mengimplemtasikan pada satuan pendidikan tersebut. Untuk itu, 
sebagai Koordinator Pelaksanan Akreditasi (KPA) sebagai perpanjangan tugas BAN S/M propinsi dipandang perlu untuk melakukan pendampingan tersebut. Adapun tujuan dari kegiatan pendampingan tersebut adalah 1) peningkatan pemahaman tentang akreditasi mengacu pada IASP 2020 , 2) kelengkapan dokumen sebagai buktii fisik akreditasi sehingga nantinya dapat meningkatkan status akreditasi.

\section{METODE PELAKSANAAN}

Kegiatan pendampingan penyusunan dokumen instrumen akreditasi satuan pendidikan (IASP) 2020 di SD Negeri Late, dilakukan dalam bentuk kegiatan pengabdian masyarakat dengan tahapan sebagai berikut: 1) Observasi awal. Kegiatan Observasi dilakukan untuk mendapat gambaran awal tentang mendapat gambaran umum permasalahan atau kesulitan yang dihadapi oleh kepala Sekolah dan seluruh tenaga pendidik dan kependidikan sebagai skala prioritas permasalahan yang harus segera dicarikan solusinya, dalam kegiatan pendampingan penyusunan borang akreditasi 2020. 2) pelatihan dan pendampingan. Kegiatan pelatihan dan pendampingan dilakukan untuk memberikan pemahaman sekaligus pendampingan teknik menyusun borang akreditasi menggunakan IASP 2020, serta berkas dokumen yang diperlukan untuk di unggah ke SISPENA 3) evaluasi. Evaluasi dilakukan untuk mengukur tingkat pemahaman kepala sekolah dan guru-guru tentang IASP 2020. 4) Refleksi yang dikumpulkan melalui wawancara, observasi dan telaah dokumen. Pada tahap ini dilakukan untuk mengukur secara keseluruhan kesiapan sekolah dalam mengahdapai Visitasi Akreditasi. Waktu Pelaksanaan kegiatan pendampingan penyusunan dilaksanakan dari bulan Februari 2021 Maret 2021

\section{HASIL DAN PEMBAHASAN}

\section{Gambaran Umum Program kegiatan Penyusunan Borang Akreditasi Bagi Sekolah Dasar Negeri Late}

Kegiatan pendampingan penyusunan dokumen instrumen akreditasi satuan pendidikan (IASP) 2020 di SD Negeri Late, dilakukan dalam bentuk kegiatan pengabdian masyarakat dengan tahapan sebagai berikut: 1) Observasi awal, 2) Ceramah, 3) pelatihan dan pendampingan 4) evaluasi dan 5) Refleksi yang dikumpulkan melalui wawancara, observasi dan telaah dokumen. 
Tahapan kegiatan yang merupakan metode pelaksanaan kegiatan dijabarkan sebagai berikut:

1) Observasi Awal

Kegiatan yang dilakukan pada tahap observasi awal adalah melakukan wawancara yang mendalam dengan kepala sekolah sebagai manajer Sekolah Dasar Negeri Late,untuk mendapat gambaran umum permasalahan atau kesulitan yang dihadapi oleh kepala Sekolah dan seluruh tenaga pendidik dan kependidikan sebagai skala prioritas permasalahan yang harus segera dicarikan solusinya, dalam kegiatan pendampingan penyusunan borang akreditasi 2020. Dari hasil wawancara Pelaksanaan kegiatan pengabdian diperoleh bahwa sekolah sangat membutuhkan pendampingan penyusunan borang karediatsi IASP 2020 karena terjadi pergesarean paradigma IASP 2020 dan kurangnya pemahaman kepala sekolah, tenaga pendidikdan kependidikan, tentang perubahaan paradigma IASP 2020. Menurut wahyuni (2018) manjerial kepala sekolah dan tenaga pendidikan dan kependidikan di suati lembaga sekolah sangat berdampak pada peningkatan mutu sekolah tersebut yang mengacu pada standar nasional pendidikan (SNP).

2) Ceramah

Berdasarkan permasaalhan yang dipaparkan, ruang linkup materi pelatihan meliputi 1) Kebijakan BAN S/M propinsi NTT, 2) Reformasi Akreditasi sekolah/Madrasah dan konsep dasar IASP 2020, 3) Telaah butir Komponen mutu IASP 2020, 4) Teknik pengisian borang melalai DIA SISPENA, 5) penilaian IASP 2020. Kegiatan dilaksanakan selama 2 hari terhitung dari tanggal $10-11$ Maret 2021 dengan jumlah peserta 9 orang. Hari pertama dilakukan pemaparan materi secara umum berkaitan dengan: 1). Kebijakan BAN S/M propinsi NTT, 2) Reformasi Akreditasi sekolah/Madrasah dan konsep dasar IASP 2020, dimana Terjadinya Pergeseran dari compliance ke performance; dari rules ke principles dengan tetap mempertimbangkan standar nasional pendidikan, Penekanan diberikan kepada kompetensi lulusan dan proses pendidikan, mutu guru, dan manajemen sekolah, Kompetensi lulusan merupakan hasil dari proses pembelajaran, mutu guru, yang didukung oleh manajemen sekolah yang efektif dan efisien . Pada akreditasi 2021, sekolah/madrasah sasaran visitasi harus memenuhi persyaratan mutlak yang ditentukan oleh BAN-S/M untuk dapat divisitasi. Asesmen kecukupan adalah proses penilaian kecukupan terhadap sekolah/madrasah yang telah memenuhi: (1) indikator pemenuhan mutlak (IPM), (2) kelengkapan indikator pemenuhan relatif (IPR), (3) kelengkapan data isian akreditasi (DIA), dan (4) kelengkapan dokumen yang diunggah. Kegiatan asesmen kecukupan ini merupakan bagian dari rangkaian kegiatan visitasi yang dilakukan oleh asesor. BAN-S/M menetapkan 2 (dua) orang asesor yang akan bertugas di setiap sekolah/madrasah melalui aplikasi Sispena-S/M yang kemudian penugasannya ditetapkan oleh BAN-S/M Provinsi3) Telaah 
butir Komponen mutu IASP 2020, 4) Teknik pengisian borang, 5) penilaian IASP 2020. Dalam kegiatan ceramah ada beberapa hal yang harus ditekankan berkaitan dengan mekanisme pelaksanaan akreditasi menggunakan IASP 2020 yaitu seperti dipaparkan pada diagram berikut ini.

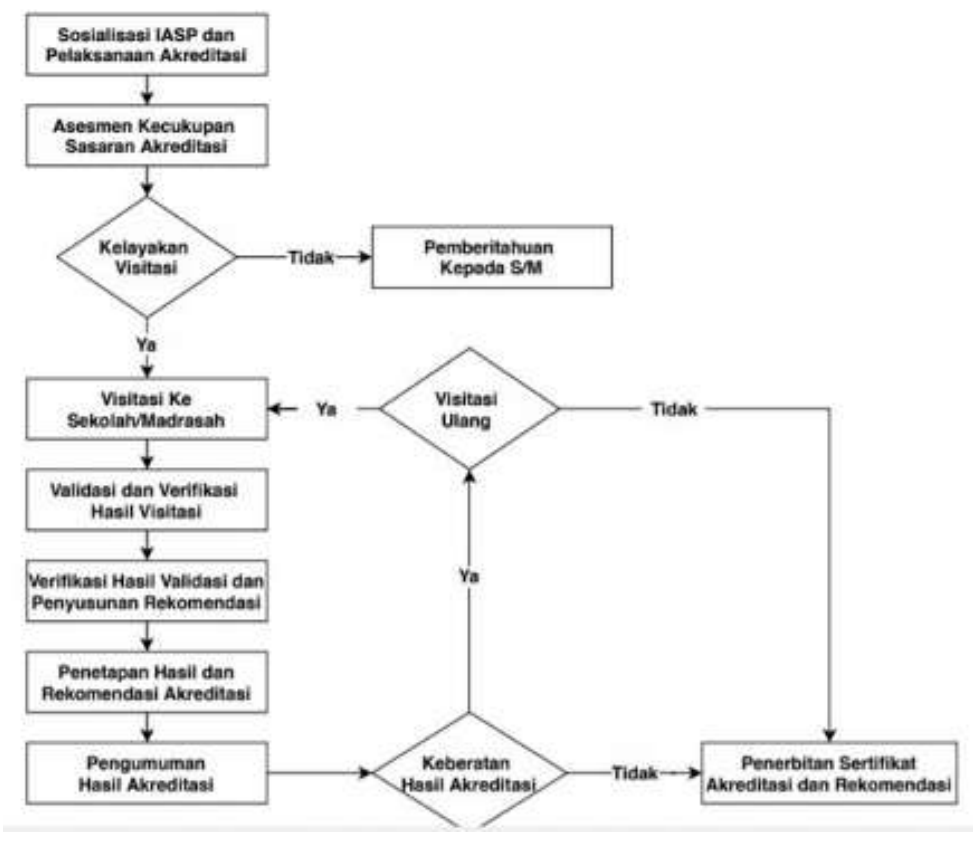

\section{Gambar 01. Alur Proses Akreditasi Sekolah/Madrasah}

\section{3) Pelatihan dan Pendampingan}

Kegiatan pelatihan dan pendampingan dilaksanakan pada hari kedua yaitu pada tanggal 11 Maret 2021 dengan agenda praktik penyusunan dokumen sesuai dengan IASP 2020. Tujuan dari kegiatan pelatihan dan pendampingan, untuk mendampingi sekolah dasar Negeri Late dalam mengisi DIA Sispena serta bagaimana menyiapkan bukti fisik borang akreditasi mengacu pada IASP 2020. Pendampingan dilaksanakan ditekankan pada focus grup diskusi berkaitan dengan persiapan dokumen yang dijadikan sebagai bahan penilaian akreditasi dan teknik pengisian borang akreditasi secara online memuat empat komponen utama yaitu pertama, komponen mutu lulusan y ang dijabarkan kedalam 4 sub komponen yaitu Karakter Siswa 4 butir ( butir 1-4) Kompetensi Siswa 4 butir ( butir 5- 8 ) Kepuasan Pemangku Kepentingan 1 butir ( butir 9). Kedua Komponen mutu proses pembelajaran terdiri dari sub komponen Kualitas Pembelajaran di Kelas 3 butir (butir 10 - 12) Iklim Belajar di Kelas 2 butir ( butir 13-14) dan komponen Pemanfaatan Sarana dan Prasarana Penunjang Proses Pembelajaran terdiri 1 butir yaitu butir 15. Ketiga, Kompetensi Guru butir 16 ( 1 butir), Pengembangan Profesi Guru butir 17 -18 ( 2 butir), dan sub komponen inovasi dan 
kreativitas guru butir 19 ( 1 butir). keempat komponen Manajemen Sekolah/Madrasah yang terdiri sub komponen Pencapaian Visi dan Misi, butir 20 (1 butir), Kompetensi Supervisi kepala sekolah/madrasah, butir 21( 1 butir), Kepemimpinan Kepala Sekolah/Madrasah, butir 22 ( 1 butir), Budaya Sekolah/Madrasah butir 23-24 ( 2 butir), Pelibatan Masyarakat, butir 25 (1 butir), Pengelolaan Kurikulum, 1 butir (butir 26), Pengelolaan Guru dan Tenaga Kependidikan, butir 27 ( 1 butir), Pengelolaan Sarana dan Prasarana, butir 28 (1 butir), Pengelolaan Pembiayaaan, butir 29 - 30 (2 butir) Pengelolaan Kesiswaan butir 31-33 (3 butir) dan butir kekhususan 1 butir yaitu memuat tentang mutu guru yang berkaitan dengan keterampilan guru dalam menyusun perangkat pembelajaran tematik atau yang disebut dengan Rencana pelaksanaan pembelajran tematik. Pada tahap pendampingan peserta dibimbing bagaimana memngisi isntrumen melalui DIA SISPENA dan dokumen yang harus disiapkan dan dokumen yang harus diinput di DIA SISPENA. Salah satu contoh yang dipaparkan pada gambar berikut ini bagiamana sekolah menginput melalui DIA SISPENA.

Langkah I

Bukaur: $h$ https//bansm kemdikbud goid/sispena2020/login
di halaman browser.

$x+$

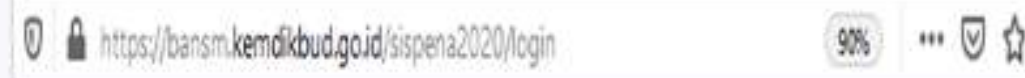

Gambar 02. Langkah I membuka Browser aplikasi SISPENA

Langkah 2

Akan muncul halaman login Seperti terlihat di bawah ini.

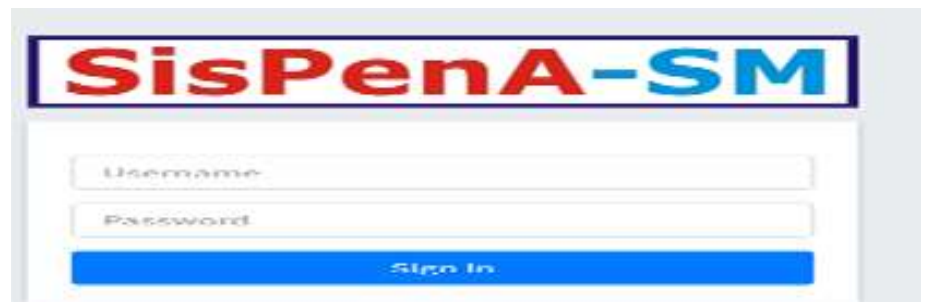

Gambar 03. Tampilan Awal Menu Sispena 
Langkah 3

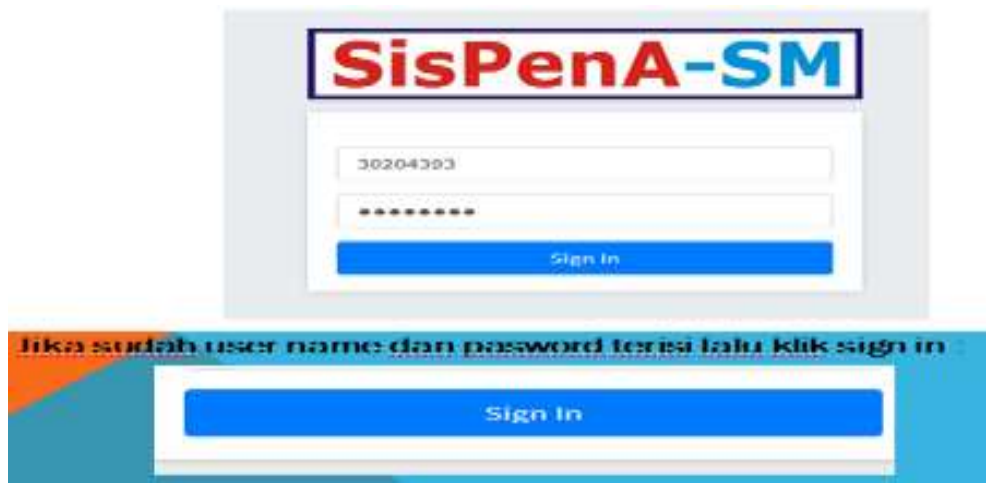

Gambar 04. Langkah 3 menginput username dan Password

Langkah 4

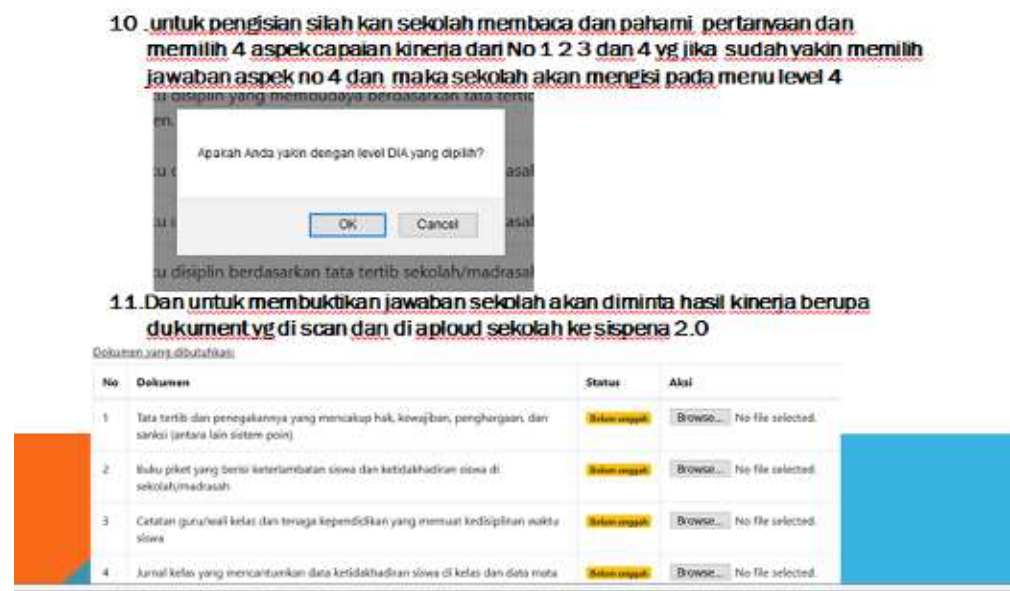

Gambar 05. Tampilan Instrumen yang akan di Isi oleh Sekolah

Langkah 5

12. Jika sekolah sudah berhasil memilih level maka akan bewama hijau pada menu level

DIA
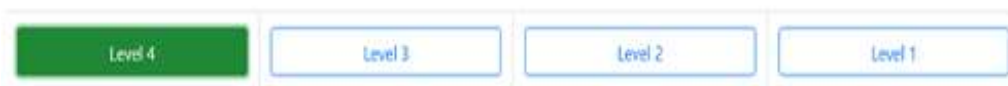

13 jika sekolah ingin kembali mengedit jawaban maka silah kan klik level yg diingikan

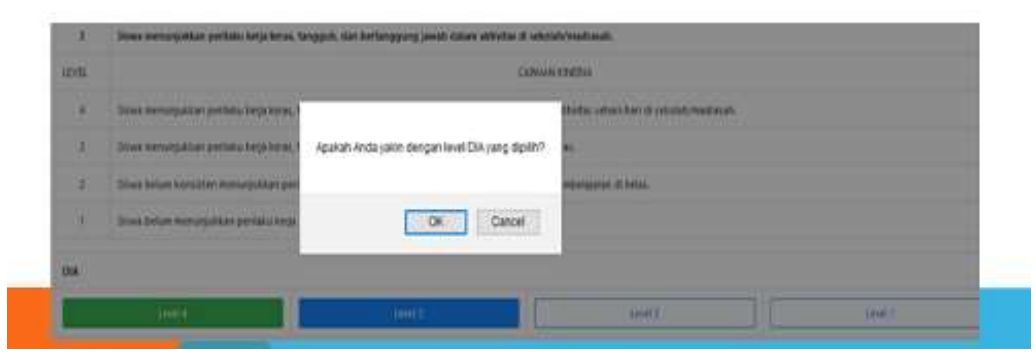

Gambar 06. Tampilan Jika Sekolah menginput dengan Benar dan Mengeditnya 
Langkah 6

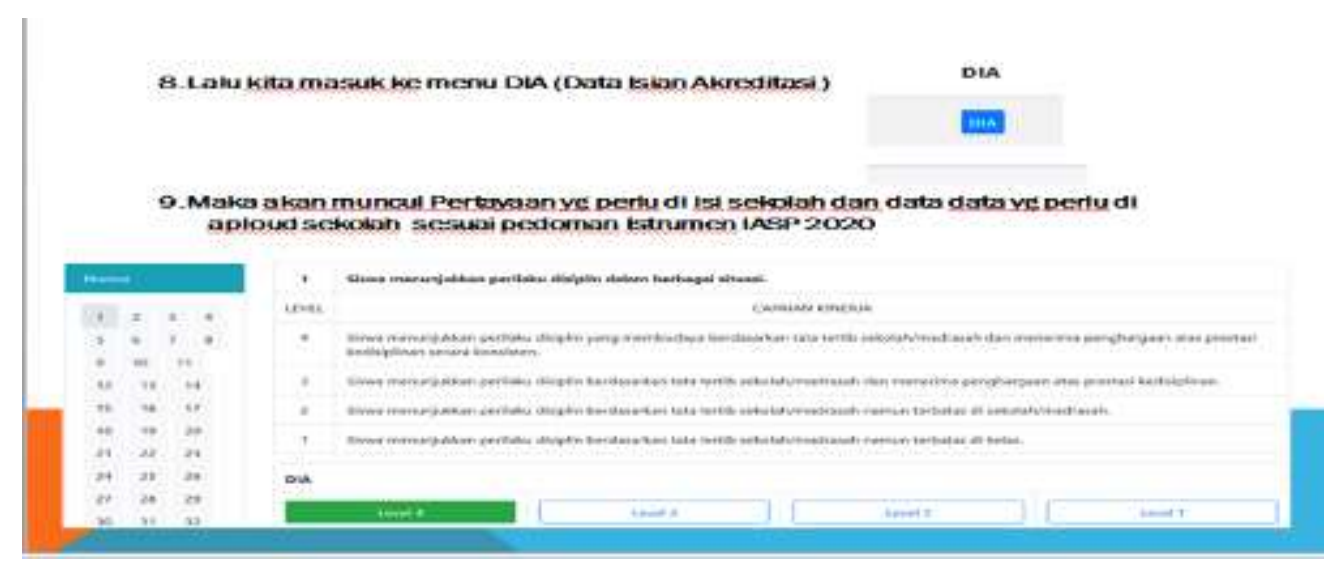

Gambar 07. Menginput Dokumen pada Menu DIA

Langkah 7

5. Setelah terisiselanjutrya klik Submit

6. Jika sudah selesai maka lanjut Klik Menu Pengisłan DIA

ᄉ

Data Isian Akreditasi (DIA)

7. Maka akan muncul dokumen sekolah dan DIA ,

Penilaian Sekolah

Penilaian

No NDSN

3020039

Nama Soknobh

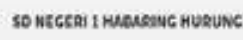

senjang

Dokumen Seckolat

so/un

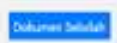

DIA

102063

\section{Gambar 08. Tahap Akhir pengisian Sispena}

4) Evaluasi

Setelah proses pelatihan dan pendampingan selesai, untuk mengetahui dampak dari kegiatan maka dilakukan evaluasi. Evaluasi dilakukan terhadap kulaitas dokumen yang dihasilkan. Evaluasi ini dilakukan dengan melakukan penilaian akreditasi yang serupa dengan penilaian akreditasi sekolah yang dilaksanakan oleh Badan Akreditasi Sekolah/ madrasah. Hasil evalausi menunjukkan bahwa sekolah SDN Late siap untuk melaksanakan akreditasi pada tahun 2021 dengan menggunakan IASP 2020. Hasil ini diperkuat dengan dokumen yang dikembangankan sesuai dengan instrumen. Kepala Sekolah, tenaga penddik dan tenaga kependidikan sudah memahami tentang persiapan dokumen borang dan cara mengisi data melalui DIA Sispena. 


\section{5) Refleksi}

Refleksi merupakan tahap akhir dari kegiatan pengabdian yang dilakukan. Refleksi dilakukan terkait pelaksanaan program kegiatan pendampingan dari awal sampai akhir, melalui observasi dan wawancara. Hasil refleksi diperoleh melalui kegiatan pengabdian dapat menukar informasi, sharing pengalaman terkait akreditasi dalam peningkatan mutu pendidikan.

\section{Pembahasan}

Setelah proses pelatihan dan pendampingan selesai, untuk mengetahui dampak dari kegiatan maka dilakukan evaluasi. Evaluasi dilakukan terhadap kulaitas dokumen yang dihasilkan. Evaluasi ini dilakukan dengan melakukan penilaian akreditasi yang serupa dengan penilaian akreditasi sekolah yang dilaksanakan oleh Badan Akreditasi Sekolah/ madrasah. Hasil evalausi menunjukkan bahwa sekolah SDN Late siap untuk melaksanakan akreditasi pada tahun 2021 dengan menggunakan IASP 2020. Hasil ini diperkuat dengan dokumen yang dikembangankan sesuai dengan instrumen. Kepala Sekolah, tenaga penddik dan tenaga kependidikan sudah memahami tentang persiapan dokumen borang dan cara mengisi data melalui DIA Sispena.

Sesuai tujuan yang ingin diharapkan dari kegiatan ini adalah adanya pemahaman yang mendalam tentang penyusunan borang akreditasi dan kelengkapan dokumen sebagai bukti fisiknya dapat menambah pengetahuan tentang penyusunan borang akreditasi sekolah dan kelengkapan dokumen fisik akreditasi sehingga nantinya dapat meningkatkan status akreditasi. Dari hasil kegiatan yang dilaksanakan dapat disimpulkan adanya peningkatan pemahaman dan kesadaran kepala Sekolah, guru dan tenaga kependidikan tentang akreditasi sebagai salah satu faktor dalam meningkatkan mutu pendidikan, dimana pada tahap observasi awal kepala sekolah dan tenaga pendidik dan kependidikan di SDN Late belum memahami perubahaan paradigma tentang akreditasi dengan menggunakan IASP 2020. Setelah dilakukan kegiatan pendampingan, Kepala sekolah, tenaga pendidik dan tenaga kependidikan sangat memahami tentang paradigma perubahaan akreditasi dengan menggunakan IASP 2020. Tingkat pemahaman dari Kepala Sekolah, tenaga pendidik dan tenaga kependidikan ini diwujudnyatakan dengan persiapan dokumen yang lengkap mengacu pada IASP 2020, yaitu dokumen pada komponen mutu lulusan, mutu proses pembelajaran, mutu tenaga Pendidik, dan Mutu manajemen sekolah. Dokumen dokumen yang dimaksudkan adalah dokumen yang diminta sesuai dengan butir-butir instrumen akreditasi dari dokumen kebijakan kepala sekolah terkait program kerja sekolah, bukti-bukti kinerja dan sampai pada tahap evalausi program kerja. 


\section{KESIMPULAN}

Hasil analisis evaluasi pelaksanaan program pendampingan penyusunan boring akreditasi bagi Sekolah Dasar Negeri Late disimpulkan bahwa adanya peningkatan pemahaman dan kesadaran kepala Sekolah, guru dan tenaga kependidikan tentang akreditasi sebagai salah satu faktor dalam meningkatkan mutu pendidikan. Tingkat pemahaman dari Kepala Sekolah, tenaga pendidik dan tenaga kependidikan ini diwujudnyatakan dengan persiapan dokumen yang lengkap mengacu pada IASP 2020, yaitu dokumen pada komponen mutu lulusan, mutu proses pembelajaran, mutu tenaga Pendidik, dan Mutu manajemen sekolah. Dokumen dokumen yang dimaksudkan adalah dokumen yang diminta sesuai dengan butir-butir instrumen akreditasi dari dokumen kebijakan kepala sekolah terkait program kerja sekolah, bukti-bukti kinerja dan sampai pada tahap evalausi program kerja. Kegiatan pengabdian yang dilakukan menjadi faslitasi sekolah dan institusi STKIP Citra bakti untuk menjadi mitra kerja yang baik.

\section{DAFTAR PUSTAKA}

Antonius, A. (2017). Pelaksanaan Akreditasi Sekolah Dasar Negeri. FOKUS: Publikasi IImiah Untuk Mahasiswa, Staf Pengajar Dan Alumni Universitas Kapuas Sintang., 14(2), 250-258. https://doi.org/10.51826/fokus.v14i2.44

M. Zulkifli. (2015). KINERJA BADAN AKREDITASI PROVINSI SEKOLAH/MADRASAH (BAP S/M) DALAM MENINGKATKAN MUTU PENDIDIKAN DI PROVINSI SULAWESI TENGGARA Zulkifli.M. Jurnal Al-Ta'dib, 8(2), 168-190.

Malik, Abdul, dkk. (2021). Pedoman Akreditasi Sekolah dan Madrasah Tahun 2021.

Minuchin. (2003). Undang-Undang No 20 Tahun 2003 Tentang Sistem pendidikan Nasional, $4(1), 147-173$.

Subijanto \& Siswo Wiratno. (2012). Analisis Kinerja Badan Akreditasi Nasional Sekolah/Madrasah The Performance Analysis of the National Acreditation Board for School/Madrasah. Jurnal Pendidikan Dan Kebudayaan, 18(3), 310-318.

Wewe, M. (2014). PENGARUH PEMBELAJARAN KOOPERATIF TIPE STAD TERHADAP HASIL BELAJAR MATEMATIKA PADA POKOK BAHASAN SISTEM PERSAMAAN LINIER DUA VARIABEL DI KELAS VIII SMP NEGERI 4 BAJAWA TAHUN THE EFFECT OF STAD TYPE COOPERATIVE LEARNING TO THE LEARNING ACHIEVEMENT OF MATH O, 1(1), 27-32.

Wewe, M. \&, \& Kau, H. (2019). ETNOMATIKA BAJAWA: KAJIAN SIMBOL BUDAYA BAJAWA. Jurnal Ilmiah Pendidikan Citra Bakti, 6(2), 121-133. https://doi.org/10.5281/zenodo.3551652

Wewe, M., Rawa, N. R., Bela, M. E., Wangge, M. C. T., \& Bhoke, W. (2020). Penyusunan Instrumen Tes Berbasis High Order Thinking Skill Di Smak St. Joanne Baptista Wolosambi. Jurnal Abdimas Ilmiah Citra Bakti, 1(1), 64-71. https://doi.org/10.38048/jailcb.v1i1.80 